\title{
Case Report: Primary Orbital Squamous Cell Carcinoma
}

\author{
Alexander D. Blandford ${ }^{a} \quad$ Claudine Bellerive $^{a}$ Martin Tom $^{b} \quad$ Shlomo Koyfman $^{b}$ \\ David J. Adelstein ${ }^{c}$ Thomas P. Plesec ${ }^{d} \quad$ Julian D. Perry ${ }^{a}$ Arun D. Singh ${ }^{a}$

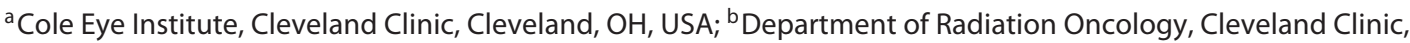

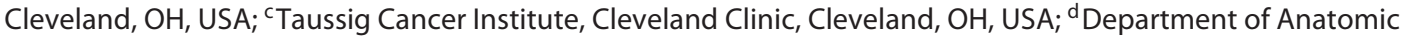 \\ Pathology, Cleveland Clinic, Cleveland, OH, USA
}

\section{Established Facts}

- Orbital squamous cell carcinoma is rare and usually the result of perineural invasion from a cutaneous lesion.

- Primary orbital squamous cell carcinoma is exceedingly rare with less than 10 known cases reported.

\section{Novel Insights}

- Primary orbital squamous cell carcinoma is a diagnosis of exclusion and can be well treated with a multidisciplinary team involving surgical biopsy, adjuvant orbital radiation, and chemotherapy.

\section{Keywords}

Orbital tumor · Squamous cell carcinoma · Orbital radiation · Primary

\section{Abstract}

Squamous cell carcinoma (SCC) of the orbit is almost uniformly the result of local invasion from a cutaneous primary, extension by perineural invasion, or the result of metastasis. This is owed to the lack of native squamous epithelium in the orbit. After review of the literature, to date, only 6 reports of 8 patients with primary orbital SCC exist. Of those cases, only 2 reported non-apical orbital SCC. There are 2 reports of orbital SCC after retina surgery with proposed transplanted conjunctival epithelium and subsequent ma- lignant transformation of a conjunctival cyst. The initial signs and symptoms can be vague and lead to delay in diagnosis. We present a case of primary orbital SCC and discuss the workup, imaging, and multidisciplinary management of this rare condition.

๑) 2018 S. Karger AG, Basel

\section{Introduction}

Primary orbital squamous cell carcinoma (SCC) arising de novo is an extremely rare entity. There are 2 reports of orbital SCC after retina surgery with proposed transplanted conjunctival epithelium and subsequent malignant transformation of a conjunctival cyst $[1,2]$.

\section{KARGER}

(c) 2018 S. Karger AG, Basel

E-Mail karger@karger.com

www.karger.com/oop
Alexander D. Blandford, MD

Cole Eye Institute, Cleveland Clinic

9500 Euclid Avenue, Desk i-13

Cleveland, $\mathrm{OH} 44195$ (USA)

E-Mail adblandford@gmail.com 
Other reports have shown orbital SCC as the result of malignant transformation of orbital cysts or the lacrimal gland [3-8]. There are only 6 case reports of a total of 8 patients in the literature with primary orbital SCC; the most recent from an Argentinian group in 2017, one from a 2014 report by a Korean group, another report in 2014 as a reply to the 3 cases from a multicenter report in 2012 by Peckinpaugh et al., a 2011 report from the United Kingdom, and the first report from Ruff et al. in 1985 [9-14]. We present the ninth known case of primary orbital SCC and only the third known case of non-apical disease. This report followed guidelines to be HIPAA compliant and permission was obtained from the patient to publish identifiable photographs. The study adhered to the tenets of the Declaration of Helsinki. The presentation, delayed diagnosis, multidisciplinary management, and review of the literature are described.

\section{Case Report}

A 63-year-old Caucasian man with a history of prior central chest, right back, left cheek, and left forehead basal cell carcinoma, all status post resection, presented to the clinic for evaluation of right ophthalmic division pain and numbness. Beginning 1.5 years prior, the patient developed right forehead numbness and intermittent pain. His workup at the time involved neurology evalua-

Fig. 1. MRI of the brain showing coronal (a) and axial (b) scans of patient 5/2015 with no orbital mass and coronal (c) and axial (d) scans of patient 7/2016 revealing a new $\sim 1.5-\mathrm{cm}$ well-circumscribed superomedial orbital mass.
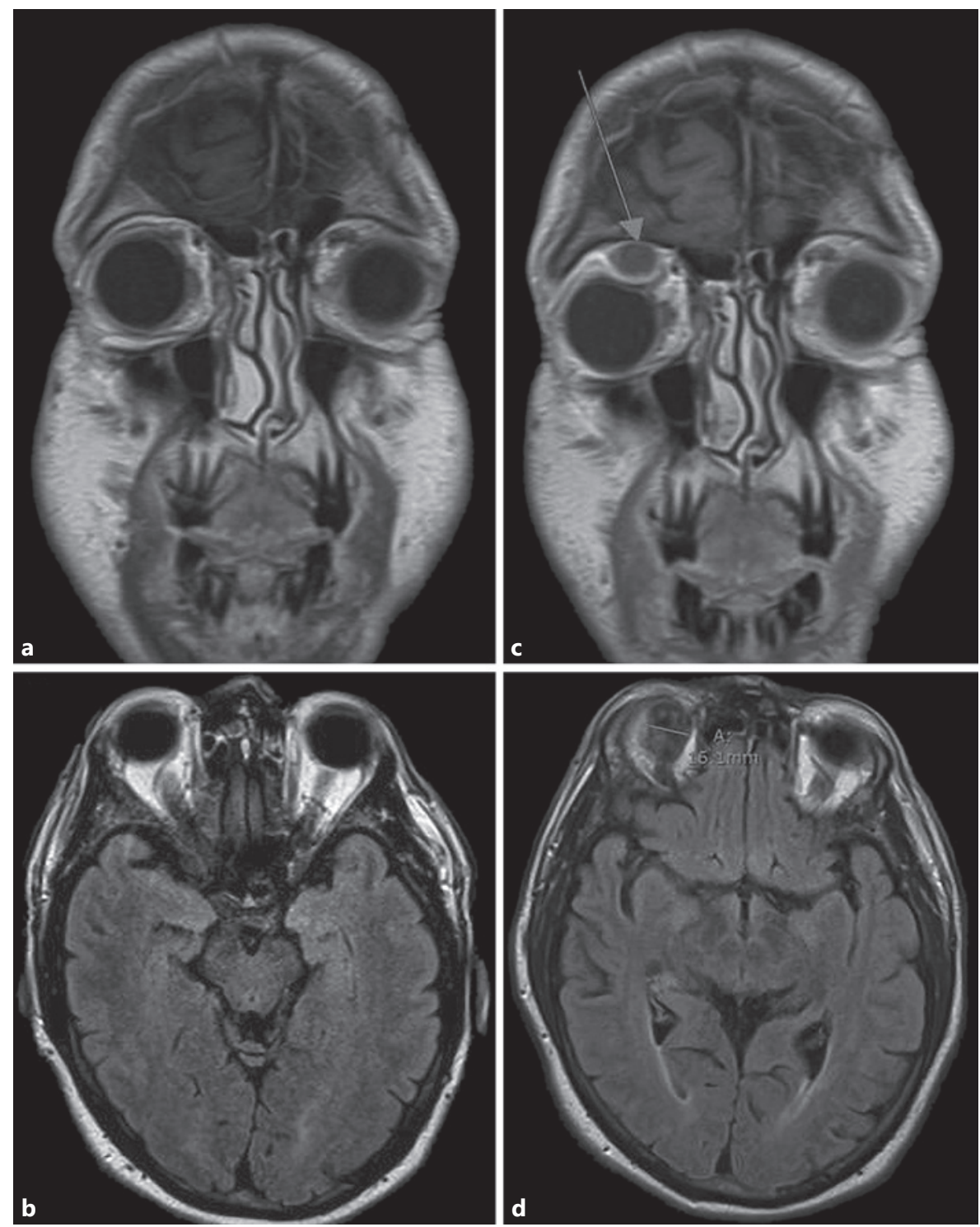
tion and an MRI of the brain, which revealed no lesions or explanation of symptoms. His symptoms progressed over the next year including transient blurry vision and more frequent right forehead pain, prompting him to seek evaluation by his local ophthalmologist. At that time, his ophthalmologic exam was reported as normal and again no explanation of his symptoms was given. Two months later, he presented to a local emergency department for persistent right forehead numbness and pain as well as the new development of right ptosis and diplopia. An MRI of the brain was repeated and revealed a new $1.5-\mathrm{cm}$ superomedial well-circumscribed orbital mass (Fig. 1).

This led to his referral to our tertiary referral center at the Cole Eye Institute, where he was found to have best corrected vision of $20 / 25$, no afferent pupillary defect, and intact color vision in both eyes. His exam revealed some limitation in supraduction of the right eye, $5 \mathrm{~mm}$ of right proptosis, and a firm round palpable 10 $\times 10 \mathrm{~mm}$ mass in the superomedial right orbit with numbness in the distribution of right V1 over his right forehead. External ocular adnexa, anterior segment, and dilated fundus exam were otherwise unremarkable. The patient underwent an orbitotomy via an upper eyelid crease approach 1 week later. Incisional biopsy of the well-demarcated lesion revealed "putty-like" contents that were consistent with an invasive keratinizing SCC. To guide the final management, the decision was made to hold on complete excision until discussion with the patient regarding treatment options such as exenteration versus total excision with adjuvant chemotherapy and radiation therapy in consultation with radiation oncology.

To assist with management, full-body PET-CT surveillance was performed and demonstrated a $1.4-\mathrm{cm}$ confined lesion of the right superomedial orbit without lymph node involvement or evidence of metastasis. One week later, the patient underwent repeat orbitotomy with complete excision of lesion, which was found to measure $3.0 \times 1.1 \times 0.9 \mathrm{~cm}$. The lesion was found to be encapsulated and adherent to the periosteum, but did not involve the orbital bone. Histopathology revealed well-differentiated invasive
SCC with clear margins and no evidence of perineural spread (Fig. 2). The patient was placed on a prednisone taper and topical steroid antibiotic ointment and recovered well in the immediate postoperative period with stable best corrected vision and no afferent pupillary defect.

In consultation with solid tumor oncology and radiation oncology services, due to concern for microscopic residual disease, the decision was made to initiate adjuvant chemotherapy and radiation therapy to decrease the risk of local recurrence. The patient received 7 weekly infusions of cisplatin $40 \mathrm{mg} / \mathrm{m}^{2}$ and concurrent radiotherapy to a total dose of 57.6 Gy over 32 fractions. Intensity-modulated radiotherapy was utilized to en-

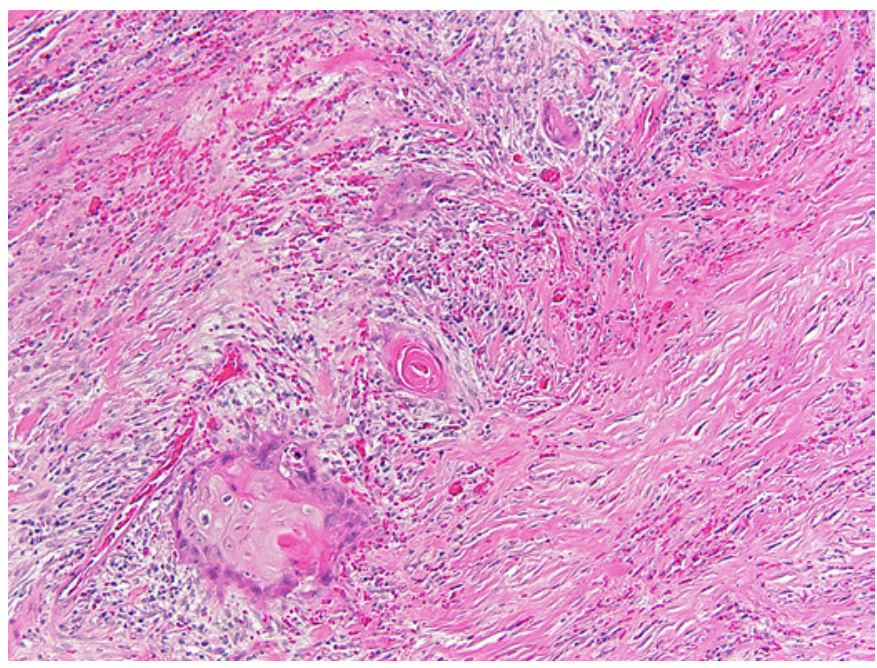

Fig. 2. Histopathology of excisional biopsy. Photomicrograph of nerve segment with no evidence of invasive carcinoma (hematoxylin and eosin, original magnification $\times 200$ ).
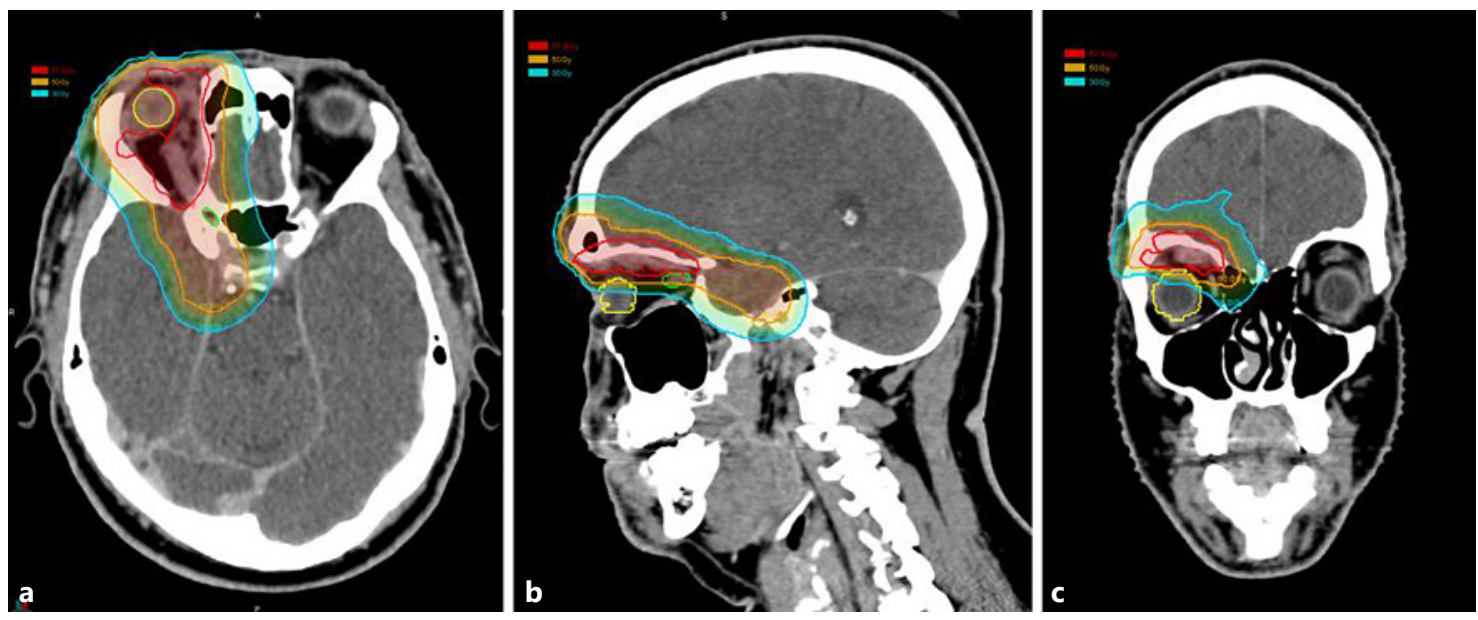

Fig. 3. Intensity-modulated radiotherapy plan dose distribution in the axial (a), sagittal (b), and coronal (c) planes with the $57.6 \mathrm{~Gy}$ (red), $50 \mathrm{~Gy}$ (orange), and $30 \mathrm{~Gy}$ (blue) isodose lines. Avoidance structures included the right globe (yellow) and optic nerve (green). 
sure adequate dose to the target volume while minimizing radiation dose to the surrounding organs at risk, including the globe, cochlea, optic nerve, and the central nervous system (Fig. 3).

At the last exam, 16 months after completion of chemotherapy and radiation therapy, his best corrected vision was 20/25 in both eyes, and there was resolution of globe displacement and no evidence of recurrence on clinical examination and by MRI.

\section{Discussion}

To our knowledge, only 6 other cases of primary orbital SCC are known. Other than our report, only two other cases of non-apical primary orbital SCC have been reported. The characteristics of these cases are summarized in Table 1 [9-14]. While orbital SCC secondary to

Table 1. Characteristics of reported primary orbital squamous cell carcinoma

\begin{tabular}{|c|c|c|c|c|c|c|c|}
\hline $\begin{array}{l}\text { Author } \\
\text { and year }\end{array}$ & Age & Sex & $\begin{array}{l}\text { Duration of } \\
\text { symptoms before } \\
\text { diagnosis }\end{array}$ & Symptoms & Workup & $\begin{array}{l}\text { Size and location } \\
\text { of tumor }\end{array}$ & Management \\
\hline $\begin{array}{l}\text { Ruff et al. } \\
1985\end{array}$ & 53 & $\mathrm{~F}$ & 2 months & Left facial pain & $\begin{array}{l}\text { Multiple exams, CT face, } \\
\text { exploratory excisional biopsy } \\
\text { of zygomaticofacial lesion } \\
\text { extending into inferolateral } \\
\text { orbital floor, maxillary sinus } \\
\text { biopsy }\end{array}$ & $\begin{array}{l}\text { Size not reported; } \\
\text { inferolateral orbit }\end{array}$ & $\begin{array}{l}\text { Nasopharynx and } \\
\text { tonsil biopsy, gal- } \\
\text { lium scan, orbital } \\
\text { radiation }\end{array}$ \\
\hline $\begin{array}{l}\text { Saha et al. } \\
2011\end{array}$ & 56 & $\mathrm{~F}$ & 18 years & $\begin{array}{l}\text { Right forehead and cheek } \\
\text { numbness, diplopia. Sub- } \\
\text { sequent right eye pain and } \\
\text { blurry vision }\end{array}$ & $\begin{array}{l}\text { MRI brain, orbit, sinus (ini- } \\
\text { tially negative), repeat MRI } \\
\text { brain, orbit } 1 \text { year later, exci- } \\
\text { sional biopsy via transfrontal } \\
\text { craniotomy, systemic evalua- } \\
\text { tion by clinical oncologist }\end{array}$ & $\begin{array}{l}\text { Size not reported: } \\
\text { orbital apex }\end{array}$ & $\begin{array}{l}\text { Primary orbital } \\
\text { radiation therapy } \\
\text { and clinical observa- } \\
\text { tion }\end{array}$ \\
\hline \multirow[t]{3}{*}{$\begin{array}{l}\text { Peckinpaugh } \\
2012\end{array}$} & 43 & $\mathrm{~F}$ & $\begin{array}{l}3 \text { months to } 8 \\
\text { years (not speci- } \\
\text { fied) }\end{array}$ & $\begin{array}{l}\text { Diplopia, ophthalmople- } \\
\text { gia, forehead numbness, } \\
\text { and upper eyelid ptosis }\end{array}$ & $\begin{array}{l}\text { Frontotemporal craniotomy } \\
\text { with biopsy, full-body CT/ } \\
\text { PET scan }\end{array}$ & $\begin{array}{l}\text { Size not reported: } \\
\text { orbital apex }\end{array}$ & $\begin{array}{l}\text { Orbital radiotherapy } \\
\text { and adjuvant che- } \\
\text { motherapy }\end{array}$ \\
\hline & 63 & M & $\begin{array}{l}3 \text { months to } 8 \\
\text { years (not speci- } \\
\text { fied) }\end{array}$ & $\begin{array}{l}\text { Diplopia, ophthalmople- } \\
\text { gia, eye pain, and forehead } \\
\text { numbness }\end{array}$ & $\begin{array}{l}\text { Frontotemporal craniotomy } \\
\text { with biopsy, full-body CT/ } \\
\text { PET scan }\end{array}$ & $\begin{array}{l}\text { Size not reported: } \\
\text { orbital apex }\end{array}$ & $\begin{array}{l}\text { Orbital radiotherapy } \\
\text { and adjuvant che- } \\
\text { motherapy }\end{array}$ \\
\hline & 67 & M & $\begin{array}{l}3 \text { months to } 8 \\
\text { years (not speci- } \\
\text { fied) }\end{array}$ & $\begin{array}{l}\text { Diplopia, ophthalmople- } \\
\text { gia, forehead numbness, } \\
\text { eye pain, and upper eyelid } \\
\text { ptosis }\end{array}$ & $\begin{array}{l}\text { Lateral orbitotomy with biop- } \\
\text { sy }\end{array}$ & $\begin{array}{l}\text { Size not reported: } \\
\text { orbital apex }\end{array}$ & Orbital radiotherapy \\
\hline $\begin{array}{l}\text { Hromas and } \\
\text { Sokol } \\
2014\end{array}$ & 46 & M & Not specified & $\begin{array}{l}\text { Decreased vision in left eye } \\
\text { and motility deficit }\end{array}$ & $\begin{array}{l}\text { MRI orbit, lateral orbitotomy } \\
\text { with excisional biopsy, full- } \\
\text { body CT/PET scan }\end{array}$ & $\begin{array}{l}\text { Size not reported; } \\
\text { inferior intraconal } \\
\text { space between } \\
\text { inferior rectus and } \\
\text { optic nerve }\end{array}$ & $\begin{array}{l}\text { Left orbital exenter- } \\
\text { ation and adjuvant } \\
\text { orbital radiation }\end{array}$ \\
\hline $\begin{array}{l}\text { Choi et al. } \\
2014\end{array}$ & 74 & $\mathrm{~F}$ & 2 months & $\begin{array}{l}\text { Left upper eyelid swelling, } \\
\text { eye pain, double vision, left } \\
\text { forehead and cheek numb- } \\
\text { ness }\end{array}$ & $\begin{array}{l}\text { MRI orbit, incisional biopsy, } \\
\text { unspecified extensive systemic } \\
\text { workup }\end{array}$ & $\begin{array}{l}2.1 \times 1.5 \times 2.0 \mathrm{~cm} \\
\text { superomedial orbit }\end{array}$ & $\begin{array}{l}\text { Left orbital exenter- } \\
\text { ation and adjuvant } \\
\text { orbital radiation }\end{array}$ \\
\hline $\begin{array}{l}\text { Campos } \\
\text { Arbulu et al. } \\
2017\end{array}$ & 73 & $\mathrm{~F}$ & 1 year & $\begin{array}{l}\text { Headache and right perior- } \\
\text { bital pain with parathesias, } \\
\text { right ptosis, and diplopia }\end{array}$ & $\begin{array}{l}\text { CT orbit, MRI orbit, incisional } \\
\text { biopsy, full-body CT/PET } \\
\text { scan }\end{array}$ & $\begin{array}{l}3.5 \mathrm{~cm} \text {; superior } \\
\text { orbit abutting } \\
\text { frontal sinus }\end{array}$ & $\begin{array}{l}\text { Craniofacial resec- } \\
\text { tion with orbital } \\
\text { exenteration with } \\
\text { adjuvant orbital } \\
\text { radiation }\end{array}$ \\
\hline $\begin{array}{l}\text { Blandford } \\
\text { et al. } \\
2018\end{array}$ & 63 & M & 18 months & $\begin{array}{l}\text { right forehead numbness, } \\
\text { right ptosis, and diplopia }\end{array}$ & $\begin{array}{l}\text { MRI brain, MRI orbit, inci- } \\
\text { sional biopsy, full-body CT/ } \\
\text { PET }\end{array}$ & $\begin{array}{l}1.5 \mathrm{~cm} \text {; superome- } \\
\text { dial orbit }\end{array}$ & $\begin{array}{l}\text { Right orbitotomy } \\
\text { with excisional } \\
\text { biopsy, adjuvant } \\
\text { chemotherapy and } \\
\text { orbital radiation }\end{array}$ \\
\hline
\end{tabular}


perineural invasion from occult cutaneous lesions is well described, our patient gave no history of any right facial lesions and none were seen on examination $[15,16]$. This was corroborated after detailed review of prior dermatology records and dermatopathology reports. A natural concern of this report is that the orbital mass may have derived from perineural spread of a cutaneous lesion that had resolved. Our patient was under the care of a dermatologist and had no prior skin lesions in that area. MRI did not indicate any evidence of perineural invasion. Moreover, histopathology of the nerve segment that was excised with the tumor was normal in appearance.

Although we have no way of confirming, it is theoretically possible that the patient had a dermoid or ectopic nest of epithelial cells sequestered during embryogenesis that subsequently underwent transformation to SCC.

Our case report was similar to previous cases in regard to similar patient age, symptoms of double vision, and facial numbness in either an ophthalmic or maxillary trigeminal nerve distribution. Interestingly, our case shared that reported by Saha et al. [10] and Campos Arbulu et al. [9], where the patient's symptoms were long-standing prior to diagnosis, with initial imaging not showing any lesion. Repeat imaging in both our case and prior reports that were performed 1 year later found a new frank mass noted at that time $[9,10]$. This should cause clinicians to have a low threshold for repeat imaging in patients with symptoms similar to the patients in these case reports, particularly if there is numbness or pain in either the ophthalmic or maxillary trigeminal distribution.

As primary orbital SCC is extremely rare, no standard accepted treatment exists. This was evident in cases reported in the literature where the management ranged from primary orbital radiation and observation to orbital exenteration with adjuvant chemotherapy and orbital radiation. To guide final management, we elected to per- form an incisional biopsy for tissue diagnosis. Frozen sections were performed on the initial incisional biopsy, revealing SCC. The decision was made to hold on complete excision until further discussion with the patient regarding treatment options such as exenteration versus total excision with adjuvant chemoradiation therapy. In our case, the mass was non-apical and excisional biopsy provided clear margins. After lengthy discussion with the patient by the multidisciplinary team the decision was made for chemoradiation therapy due to the proximity of carcinoma to the biopsy margins, the patient's symptoms of ophthalmic division neuropathy, and the risk for recurrence making globe salvage difficult.

We hope that this case provides further light on a very rare presentation of SCC and offers a treatment option for non-apical primary orbital SCC that hopes to prevent recurrence and salvage the globe.

\section{Statement of Ethics}

This report followed guidelines to be HIPAA compliant and permission was obtained from the patient to publish identifiable photographs. The study adhered to the tenets of the Declaration of Helsinki.

\section{Disclosure Statement}

None of the authors have a proprietary interest in this study or any conflicts of interest to disclose.

\section{Funding Sources}

This study was supported in part by the NIH-NEI P30 Core Grant (IP30EY025585-01A1) and Unrestricted Grant from The Research to Prevent Blindness, Inc., awarded to the Cole Eye Institute.

\section{References}

1 Loffler KU, Witschel H: Orbital squamous cell carcinoma after retinal detachment surgery. Br J Ophthalmol 1991;75:568-571.

2 Lee LR, Sullivan TJ, Vandeleur K: Orbital squamous cell carcinoma following retinal detachment surgery. Aust N Z J Ophthalmol 1997;25:75-77.

3 Wright J, Morgan G: Squamous cell carcinoma developing in an orbital cyst. Arch Ophthalmol 1977;95:635-637.
4 Holds JB, Anderson RL, Mamalis N, et al: Invasive squamous cell carcinoma arising from asymptomatic choristomatous cysts of the orbit. Two cases and a review of the literature. Ophthalmology 1993;100:1244-1252.

5 Milbratz GH, Borges FP, Cintra MB, et al: Orbital invasion by squamous cell carcinoma arising in multiple epidermoid cysts. Ophthal Plast Reconstr Surg 2012;28:e144-e145.
6 Su GW, Patipa M, Font RL: Primary squamous cell carcinoma arising from an epithelium-lined cyst of the lacrimal gland. Ophthal Plast Reconstr Surg 2005;21:383-385.

7 Fenton S, Srinivasan S, Harnett A, et al: Primary squamous cell carcinoma of the lacrimal gland. Eye (Lond) 2003;17:424-425.

8 Hotta K, Arisawa T, Mito H, et al: Primary squamous cell carcinoma of the lacrimal gland. Clin Exp Ophthalmol 2005;33:534536. 
9 Campos Arbulu AL, Sadava EE, Sanchez Ruiz A, et al: Primary orbital squamous cell carcinoma. Medicina (B Aires) 2017;77:37-39.

10 Saha K, Bonshek R, Leatherbarrow B: Primary orbital squamous cell carcinoma. Clin Exp Ophthalmol 2011;39:582-584.

11 Peckinpaugh JL, Winn BJ, Barrett RV, et al: Isolated squamous cell carcinoma of the orbital apex. Ophthal Plast Reconstr Surg 2012; 28:e72-e74.
12 Choi DY, Lee JH, Ahn JH, et al: Primary squamous cell carcinoma of the orbit. J Korean Ophthalmol Soc 2014;55:1224-1228.

13 Hromas AR, Sokol JA: Re: "isolated squamous cell carcinoma of the orbital apex". Ophthal Plast Reconstr Surg 2014;30:442-443.

14 Ruff T, Lenis A, Diaz JA: Atypical facial pain and orbital cancer. Arch Otolaryngol 1985; 111:338-339.
15 McNab AA, Francis IC, Benger R, et al: Perineural spread of cutaneous squamous cell carcinoma via the orbit. Clinical features and outcome in 21 cases. Ophthalmology 1997; 104:1457-1462.

16 Bowyer JD, Sullivan TJ, Whitehead KJ, et al: The management of perineural spread of squamous cell carcinoma to the ocular adnexae. Ophthal Plast Reconstr Surg 2003;19:275281. 